\title{
Syphilis, hepatitis A, hepatitis B, and cytomegalovirus infection in homosexual men in Antwerp
}

\author{
C-H COESTER,* D AVONTS,* J COLAERT,† J DESMYTER,† AND P PIOT* \\ From the ${ }^{*}$ Department of Microbiology, Institute of Tropical Medicine, Antwerp, and the + Rega \\ Institute, Catholic University, Leuven, Belgium
}

SUMMARY In a homosexual communication centre in Antwerp 196 homosexual men were screened for seromarkers of syphilis, hepatitis A (HAV), hepatitis B (HBV) and cytomegalovirus ${ }_{\infty}$

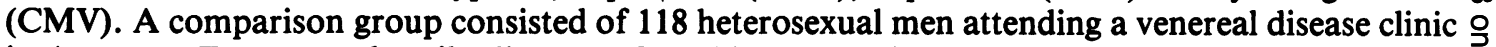
in Antwerp. Treponemal antibodies were found in $7.1 \%$ of homosexual men, of whom half gave no history of past or present infection. Anti HAV was present in 43.3\%, HBV seromarkers in $34 \cdot 4 \%$, and CMV antibodies in $71 \cdot 2 \%$ of homosexual men. Hepatitis B surface antigen (HBsAg) was detected in eight homosexual men, but not in the heterosexual control group. Prevalence rates of infections other than HAV were significantly higher in homosexual men than in heterosexual men. Answers to a questionnaire were used to evaluate risk factors for different diseases, which were: duration of active homosexuality for all infections, promiscuity $(\geqslant 10$ partners in the past six months) for syphilis and hepatitis B, and anal intercourse for hepatitis B. Visiting saunas and travelling for sexual contacts also indicated a higher risk for STD, but were an indirect expression of promiscuity.

\section{Introduction}

Active homosexual men are at high risk of acquiring sexually transmitted diseases (STD). ${ }^{1-3}$ Besides the classical venereal diseases such as syphilis and gonorrhoea there is a much higher prevalence of hepatitis B (HBV), hepatitis A (HAV), and cytomegalovirus (CMV) antibodies in the homosexual population compared with heterosexual men. ${ }^{4-6}$ Most studies were conducted in cities whose large homosexual subpopulations have international importance in gay life, and usually in centres such as saunas ${ }^{7-8}$ or STD clinics $^{49-11}$ possibly reaching only selected high risk persons. To estimate the prevalence of treponemal, HBV, HAV, and CMV antibodies in an average homosexual population, a pilot study was carried out in a gay communication centre in Antwerp, a city which is not a target of international gay travelling activity. The communication centre was chosen for screening because it is not primarily a place for sexual encounters. Furthermore, as this was the first study

Address for reprints: Dr P Piot, Department of Microbiology, Institute of Tropical Medicine, Nationalestraat 155, B-2000 Antwerp, Belgium

Accepted for publication 26 July 1983 of homosexual men in Belgium, health education was connected with blood sampling, and the participants were given a questionnaire on sexual activities and previous STD to provide information on risk factors.

\section{Materials and methods}

STUDY POPULATION

Anonymous screening was offered to visitors at a gay communication centre on consecutive weekends in October 1981 and May 1982 when there was a discotheque. All participants were given a number corresponding to that of their blood sample. Only men declaring themselves to be exclusively or pre- N dominantly homosexual were included. In October N 135 men were screened and in May there were 61 new participants and 38 repeaters. Details of residence, profession, sexual preference, age, duration of active homosexuality, and number of partners in the last six months were comparable for both groups. Data from both periods were analysed together. The questionnaire inquired about duration of active homosexuality and number of partners in the preceding six months, preferred places for sexual encounter, travel history, sexual practices, and STD history.

A control group of 118 consecutive heterosexual 
men attending the STD clinic of the Institute of Tropical Medicine in Antwerp were also studied. Only the number of sex partners in the last six months, age, and history of jaundice were recorded. Blood samples $(10 \mathrm{ml})$ were taken from all participants, and the serum was preserved at $-70^{\circ} \mathrm{C}$ within 24 hours at $4^{\circ} \mathrm{C}$.

\section{LABORATORY PROCEDURES}

All serum samples were tested by quantitative RPR (rapid plasma reagin: Hynson, West-Cott, and Dunning) and MHA-Tp (microhaemagglutination Treponema pallidum; Fujizoki) tests and for Hepatitis B surface antigen (HBsAg), anti HBs, anti Hepatitis B core (HBc), Hepatitis B e antigen $(\mathrm{HBeAg})$, anti $\mathrm{HBe}$, anti hepatitis $\mathrm{A}$ virus (HAV) IgM, and anti HAV IgG (all Abott radioimmunoassay), and complement fixing anti cytomegalovirus (CMV) antibodies (Behringwerke).

\section{STATISTICAL TESTS}

Results were analysed using the $\chi^{2}$ and Fisher's exact tests.

\section{Results}

\section{GENERAL DATA}

The average age of the homosexual participants was 28 (range 18-61) years, duration of homosexual activity 9 (range $<1-45$ ) years, and mean number of different partners within the preceding six months was five (range 0-150). Of the 196 men, $81 \%$ were exclusively homosexual. The predominant social group was office employees $(78 \cdot 6 \%)$, and $75 \%$ were Antwerp residents. The median age of the heterosexual group was 29 (range 16-61) years and number of different sex partners was three (range 1-50).

Table I lists previous episodes of STD reported by the homosexual men. In nine of the 16 who gave a history of syphilis there was no serological evidence as the MHA-Tp tests gave negative results.

\section{SEROLOGICAL DATA}

Table II summarises the results of the serological tests. Of the 14 homosexual men with positive results
TABLE I Reported history of sexually transmitted diseases by 195 homosexual men in Antwerp

\begin{tabular}{lr}
\hline No $(\%)$ of men with history of: \\
\hline Gonorrhoea, urethral & $52(26 \cdot 6)$ \\
Gonorrhoea, anal & $9(4 \cdot 6)$ \\
Syphilis & $16(8 \cdot 2)$ \\
Genital herpes & $10(5 \cdot 1)$ \\
Anal warts & $15(7 \cdot 7)$ \\
Pediculosis & $127(65 \cdot 1)$ \\
Scabies & $52(26 \cdot 6)$ \\
\hline
\end{tabular}

to the MHA-Tp test, seven gave no history of treatment for syphilis. Four of these men had positive RPR test results and were classified as having untreated syphilis (3.6\% of the study population). Of 34 giving negative results in October whose blood was retested in May, one showed positive RPR test results. Antibodies to HAV were found in about half of all men tested, but anti HAV IgM was found in only one homosexual man. Three of 21 previously seronegative homosexuals had antibodies to HAV when retested in May 1982 . Over $70 \%$ of homosexual men had antibodies to CMV, with a median titre of $1 / 64$ (range $1 / 4$ to $1 / 2048$ ). When retested seven months later, two of 13 previously seronegative men had developed CMV antibodies and three of 22 previously seropositive men had a significant rise in antibody titre.

Table III shows the distribution of different serum markers for $\mathrm{HBV}$ in the homosexual population. Eight $(4 \cdot 1 \%)$ men carried HBsAg, six of whom had e antigen. When tested seven months later, two of 26 men giving previously negative results showed a seroconversion. HBsAg was not found among the heterosexuals. Among men with serum markers for hepatitis A or B, 83 of $114(72 \cdot 8 \%)$ had not experienced jaundice. This included 21 with both HAV and HBV antibodies, and half the men with HBsAg had no history of icterus.

RISK FACTORS

Serological markers for syphilis, HAV, HBV, and CMV infection were all significantly related to duration of homosexual activity ( $p<0.005$ to $p<0.0005)$. Only serum markers for HBV, however, correlated

TABLE II Evidence of past or present infections in 196 homosexual men and in 118 heterosexual men in Antwerp

\begin{tabular}{|c|c|c|c|c|c|}
\hline \multirow[b]{2}{*}{ Infection } & \multicolumn{2}{|c|}{ Homosexual men } & \multicolumn{2}{|c|}{ Heterosexual men } & \multirow[b]{2}{*}{ Probability } \\
\hline & No tested & No (\%) positive & No tested & No $(\%)$ positive & \\
\hline $\begin{array}{l}\text { Syphilis } \\
\text { Hepatitis A } \\
\text { Hepatitis B } \\
\text { Cytomegalovirus }\end{array}$ & $\begin{array}{l}196 \\
194 \\
195 \\
191\end{array}$ & $\begin{array}{r}14(7 \cdot 1) \\
84(43 \cdot 3) \\
67(34 \cdot 4) \\
136(71 \cdot 2)\end{array}$ & $\begin{array}{r}118 \\
95 \\
66 \\
95\end{array}$ & $\begin{array}{r}2(1 \cdot 7) \\
52(54 \cdot 7) \\
8(12 \cdot 1) \\
54(56 \cdot 8)\end{array}$ & $\begin{array}{l}0.05 \\
\text { NS } \\
0.001 \\
0.025\end{array}$ \\
\hline
\end{tabular}

NS $=$ not significant. 
TABLE III Distribution of serum markers for hepatitis $B$ in 195 homosexual men in Antwerp

\begin{tabular}{clllll}
\hline \multicolumn{5}{c}{ Distribution of markers } \\
\cline { 2 - 5 } No of men & HBsAg & HBeAg & anti HBc anti HBs anti HBe \\
\hline 5 & + & + & + & - & - \\
1 & + & + & + & + & - \\
1 & + & - & + & - & + \\
1 & + & - & + & + & + \\
1 & - & NT & + & - & NT \\
3 & - & NT & - & + & NT \\
55 & - & NT & + & + & NT \\
128 & - & NT & - & - & NT \\
\hline$+=$ & & $=$ &
\end{tabular}

significantly with the number of sexual partners in the past six months (table IV). There was no correlation between the number of partners and serum markers for HAV or CMV infection.

The 181 questionnaires which were evaluable for sexual behaviour showed that almost all men $(95.6 \%)$ practised orogenital contact, which was not further evaluated as a risk factor. Anogenital contact was reported by $146(80 \cdot 7 \%)$ men of whom $27.4 \%$ had only active, $17 \cdot 1 \%$ only passive, and $55 \cdot 5 \%$ both kinds of such contact. The prevalence of seromarkers was found to be greatest in men practising both active and passive anal intercourse (table V). Oroanal contact was reported by $47.0 \%$, and men practising anilingus were $4 \cdot 12$ times more likely to have $\mathrm{HBV}$ markers than those who did not engage in oroanal sex $(p<0.0005)$. There was no correlation between anilingus and markers for other infections. Swallowing semen was not correlated with any marker.

Significantly more HBV serum markers were detected among the 91 men visiting saunas (50.0\% seropositive; $p<0.025)$. Sauna visits in this population, however, were an indication both of duration of homosexual activity and of number of partners, and not an independent risk factor. Short trips to other cities for sexual contacts were made by $\mathbf{4 7} \cdot \mathbf{2 \%}$ of homosexual men. There were significantly more HBV seropositive "travelling" men $(47 \cdot 3 \% v$ $23 \cdot 5 \%$; $<<0 \cdot 0001)$.
Men with a marker for HAV were significantly more at risk for an HBV marker and vice versa $(p<0.01)$. There was also a significant association between syphilis and HBV $(p=0 \cdot 037$; Fisher's exact test), and a positive STD history and $\mathrm{HBV}(\mathrm{p}<0 \cdot 005)$.

\section{Discussion}

Compared with studies made in saunas showing के syphilis prevalence rates of $33.9 \%$ and $19 \cdot 3 \%,{ }^{78}$ we $\vec{\circ}$ found positive reactions to MHA-Tp tests in only $7 \cdot 1 \%$ of our study population. On the other hand, $\vec{\omega}$ more than a quarter of all seropositive people were found to be untreated. This is more than in an STD clinic population ( $1 \cdot 1 \%$ untreated cases) examined by Judson. ${ }^{4}$ Only a third of our study participants gave a history of syphilis check ups. This might be one reason for the comparatively high rate of untreated cases of syphilis, in spite of the minor endemicity of the disease.

Studies on the prevalence of HBV seromarkers in homosexual men have shown that more than half $(34 \cdot 0-70 \cdot 9 \%)$ have anti $\mathrm{HBs},{ }^{6-11} 13$ whereas in our study group less than a third had anti HBs. The prevalence of $\mathrm{HBsAg}(4 \cdot 1 \%)$, however, falls within the range found in other studies $(3 \cdot 6-6 \cdot 1 \%))^{6-11} 13$ $\mathrm{HBeAg}$ is associated with a ten times greater rate of infection by needle stick exposure than HBsAg alone. ${ }^{14} \mathrm{HBeAg}$ was demonstrable in six of 13 HBsAg positive men, two of whom were traced and found to be carriers. As there is still a considerable number of susceptible individuals, our results emphasise the need for vaccination where there is risk of infection.

In a prospective study Corey showed the sexual transmission of HAV in homosexual men: ${ }^{15}$ Outbreaks were reported in Copenhagen, ${ }^{16}$ London, ${ }^{17}$ and West Berlin. ${ }^{18}$ In contrast to these findings, our study showed no significant differences in HAV antibodies between homosexuals and heterosexuals. Belgium has hepatitis A epidemiology that is similar to mediterranean rather than central or north European countries. Half the general population is seropositive by the age of $25 .{ }^{19}$ This could explain the

TABLE IV Number of sexual partners and serological markers for hepatitis $A$, hepatitis $B$, and cytomegalovirus infection in homosexual men in Antwerp

\begin{tabular}{|c|c|c|c|c|c|}
\hline \multirow{3}{*}{$\begin{array}{l}\text { Markers of past or } \\
\text { present infection }\end{array}$} & \multicolumn{4}{|c|}{ Number of different partners in the past six months } & \multirow[b]{3}{*}{ Probability } \\
\hline & \multicolumn{2}{|l|}{ One to nine } & \multicolumn{2}{|c|}{ Ten or more } & \\
\hline & No tested & No (\%) positive & No tested & No $(\%)$ positive & \\
\hline $\begin{array}{l}\text { Hepatitis B } \\
\text { Hepatitis A } \\
\text { Cytomegalovirus }\end{array}$ & $\begin{array}{l}117 \\
115 \\
114\end{array}$ & $\begin{array}{l}30(25 \cdot 6) \\
43(37 \cdot 4) \\
77(67 \cdot 5)\end{array}$ & $\begin{array}{l}53 \\
53 \\
53\end{array}$ & $\begin{array}{l}27(50 \cdot 9) \\
28(52 \cdot 8) \\
42(79 \cdot 2)\end{array}$ & $\begin{array}{l}0 \cdot 005 \\
\text { NS } \\
\text { NS }\end{array}$ \\
\hline
\end{tabular}

NS $=$ not significant. 
TABLE $\mathrm{v}$ Serum markers for hepatitis $B$ and anogenital contact

\begin{tabular}{llcc}
\hline Type of anogenital contact & $\begin{array}{l}\text { No } \\
\text { tested }\end{array}$ & $\begin{array}{l}\text { No (\%) } \\
\text { positive }\end{array}$ & $\begin{array}{l}\text { Odds } \\
\text { ratio }\end{array}$ \\
\hline None & 41 & $9(21 \cdot 9)$ & \\
Active only & 38 & $9(23 \cdot 7)$ & $1 \cdot 08$ \\
Passive only & 26 & $8(30 \cdot 8)$ & $1 \cdot 41$ \\
Both active and passive & 82 & $39(47 \cdot 6)$ & $2 \cdot 17$ \\
\hline
\end{tabular}

lack of correlation in our study group between HAV antibodies and anilingus, which is considered to be the route of transmission. ${ }^{15}$

There was a significant difference in CMV antibodies between study $(72 \cdot 1 \%)$ and control $(56 \cdot 8 \%)$ groups. This is consistent with the results of Drew and shows evidence of sexual transmission in male homosexuals.

Risk factors for acquiring STD in homosexual men are: number of different partners, duration of homosexual activity, anogenital and oroanal practices, anonymous contacts (for instance in saunas), and a positive history of any STD. ${ }^{10}$ The de facto parenteral transmission of HBV during oroanal or anogential contacts was recently shown by careful pathological studies. ${ }^{20}$ Duration of homosexuality in our study group correlated significantly with HBV, HAV, or CMV infection. For HAV, this reflects the general epidemiology rather than the possibility of sexual transmission, and this is confirmed by a lack of correlation with promiscuity. Anilingus and both active and passive anal intercourse correlated significantly with HBV seropositivity, which confirmed the results of other studies. ${ }^{11} 20$

Visiting a sauna permits multiple sexual contacts and might represent an effective exposure to infections. HBV seromarkers are significantly higher in sauna visitors, but appeared in our study to be an indicator of the duration of active homosexuality. Short trips for sexual contacts might be another indicator of promiscuity, but also provide a specific risk factor, because places favoured by gay tourism are often areas of high STD endemicity. Our results stress this association regarding HBV. In 1975 Vranckx pointed out the association of syphilis and $\mathrm{HBV}$ in blood donors in Belgium, ${ }^{21}$ which was confirmed in homosexual men by Kryger $^{10}$ and by our results.

Although Antwerp is not one of the most popular places in the international homosexual scene and has a relatively low level of syphilis, its homosexual community is at high risk of acquiring STD. Regular check ups for syphilis should be encouraged, vaccination against $\mathrm{HBV}$ should be easily available, and organisations for medical care and prevention should actively establish contact tracing and cooperate with local gay organisations.

This work was partially supported by a grant (Co-115/1-1) of Deutsche Forschungsgemeinschaft.

\section{References}

1. Darrow WW, Barett D, Jay K, Young A. The gay report on sexually transmitted diseases. Am J Public Health 1981; 71: $1004-11$.

2. Fluker JL. A 10-year study of homosexually transmitted infection. Br J Vener Dis 1976; 52: 155-60.

3. British Co-operative Clinical Group. Homosexuality and venereal disease in the United Kingdom. A second study. $B r J$ Vener Dis 1980;56:6-11.

4. Judson FN, Penley KA, Robinson ME, Smith JK. Comparative prevalence rates of sexually transmitted diseases in heterosexual and homosexual men. Am J Epidemiol 1980;112:836-43.

5. Drew WL, Mintz L, Miner RC, Sands M, Ketterer B. Prevalence of cytomegalovirus infection in homosexual men. $J$ Infect Dis 1981; 143: 188-92.

6. Dietzman DE, Harnish JP, Ray G, Alexander ER, Holmes KK. Hepatitis B surface antigen (HBsAg) and antibody to HBsAg. Prevalence in homosexual and heterosexual men. JAMA 1977; 238:2625-6.

7. Bleeker A, Coutinho RA, Bakker-Kok J, Tio D, de Koning GAJ. Prevalence of syphilis and hepatitis $B$ among homosexual men in two saunas in Amsterdam. Br J Vener Dis 1981; 57: 196-9.

8. Wolf FC, Judson FN. Intensive screening for gonorrhea, syphilis and hepatitis B in a gay bathhouse does not lower the prevalence of infection. Sex Transm Dis 1980; 7:49-52.

9. Hentzer B, Skinh øj P, Høybye G, Nielson AO, Kvorming SA, Faber V. Viral hepatitis in a venereal clinic population. Relation to certain risk factors. Scand $J$ Infect Dis 1980; 12:245-9.

10. Kryger P, Pederson NS, Mathiesen L, Nielson JO. Increased risk of infection with hepatitis $A$ and $B$ viruses in men with a history of syphilis: relation to sexual contacts. J Infect Dis 1982; 145: 23-6.

11. Schreeder MT, Thompson SE, Hadler SC, et al. Hepatitis B in homosexual men: prevalence of infection and factors related to transmission. J Infect Dis 1982; 146: 7-15.

12. Szmuness W, Much I, Prince AM, Hoofnagle JH, Cherubin CE, Harley EJ, Block GH. On the role of sexual behaviour in the spread of hepatitis B infection. Ann Intern Med 1975; 83:489-95.

13. Coleman JC, Evans BA, Thornton A, Zuckerman AJ. Homosexual hepatitis, Journal of Infection 1979:1:61-6.

14. Werner BG, Grady GF. Accidental hepatitis-B-surface-antigen-positive inoculations. Use of $e$ antigen to estimate infectivity. Ann Intern Med 1982;97:367-9.

15. Corey L, Holmes KK. Sexual transmission of hepatitis A in homosexual men. Incidence and mechanism. $N$ Engl J Med 1980; 302:435-8.

16. Hoybye G, Skinhøj P, Hentzer B, Faber V, Mathiesen L. An epidemic of acute viral hepatitis in male homosexuals. Etiology and clinical characteristics. Scand J Infect Dis 1980;12:241-4.

17. Mindel A, Tedder $\mathrm{R}$. Hepatitis $\mathrm{A}$ in homosexuals. Br Med $J$ 1981;282: 1666 .

18. Hoffmann HG, Dempe S. Hepatitis $A$ bei homosexuellen Männern. Med Welt 1983;34:77-9.

19. Vranckx R, De Decker H, Cole J, Muylle L, Peetermans $M$. Hepatitis virus $A$ antistoffen (anti-HA) bij verschillende bovolkingsgroepen uit de Antwerpse regio. Arch Belg Med Soc 1982; 10:636-42.

20. Reiner NE, Judson FN, Bond WW, Francis DP, Peterson NJ. Asymptomatic rectal mucosal lesions and hepatitis B surface antigen at sites of sexual contact in homosexual men with persistent hepatitis $B$ virus infection. Evidence for de facto parenteral transmission. Ann Intern Med 1982;96: 170-3.

21. Vranckx R. Hepatitis B antigen and serological evidence of syphilis. Lancet 1975; i: 1193. 


\section{Book review}

A book about sexually transmitted diseases. By D Cherniak, 1983. Montreal Health Press, Montreal, Canada. Pp 52.

In 1972 the Montreal Health Press published a "VD Handbook" which was widely distributed throughout North America. Changing social mores as well as advances in the microbiology of infection suggested the need for a replacement publication. In "A book about sexually transmitted diseases" the Montreal Health Press has attempted to provide an up to date and wide ranging discussion of the sexually transmitted diseases (STDs), covering society's attitudes to sex and sexuality, as well as the microbiology and management of individual infections. It has assumed a certain amount of basic knowledge among potential readers, but appears to have occasional doubts about when to simplify medical terminology-for instance, to provide a specimen of urine a woman should "urinate" but to try to prevent urinary tract infection she should "pee frequently and often". The resulting publication is a bit like the curate's egg. It is not helped by its appearance. The magazine format, with pages of typescript relieved by frequent and irrelevant black and white photographs, gives the impression that the finances available for this project were strictly limited.

\section{Corrections}

One of the authors of the paper on syphilis, hepatitis A, hepatitis B, and cytomegalovirus infection in homosexual men in Antwerp (1984; 60:48-51), Dr C-H Coester, undertook the work at the Institut für Medizinische Mikrobiologie, Freie Universität Berlin, Berlin, West Germany as well as at the Institute of Tropical Medicine, Antwerp.
Despite the unpromising appearance, the first few chapters are really rather good. A check list of common symptoms and their possible causes is followed by sections on STDs and sexuality, understanding infections, prevention and self care, dealing with an STD, and basic anatomy. These are all clear and well written and give, along with accurate information, practical and detailed advice. Some of this is applicable only to North America, but most of it would be useful on both sides of the Atlantic. The author deals with basic principles of infection and infectious diseases, and discusses what steps people can usefully take to minimise risks, including changing sexual behaviour. The chapter on "dealing with an STD" describes the medical examination of the patient in some detail with the help of drawings and diagrams. Young people often worry unnecessarily about what will happen to them during the examination, and information given like this can only be reassuring. Occasional lapses into modern sociopolitical jargon in no way diminish the value of these sections.

The success of the first part of the book serves to highlight the failure of the second, in which the author describes the diagnosis and management of individual infections. Some sections, such as the one on gonorrhoea, seem old fashioned and minatory and dwell heavily on the complications of untreated infection. Some confusion arises over diagnostic procedures, such as when the author implies that laparoscopy may be used routinely in the diagnosis of gonorrhoea. There are also numerous microbiological errors, most noticeable in the chapter on chlamydial infection. Chlamydia trachomatis is not an intermediate organism, the clinical appearance of the cervix is not a good indicator of chlamydial infection, and chlamydia should not be assumed to be the cause of urethritis if Gram negative diplococci are not present in a urethral smear.

The other sexually transmitted diseases are dealt with rather more accurately, although treatment regimens of course reflect North American practice. Patients presenting with genital symptoms may have conditions other than STDs; the inclusion of information about vaginitis, prostatitis, and urinary tract infection is helpful.

This small publication contains a great deal of information about sexually transmitted diseases and their implications for the individual and for society. Many medical textbooks contain rather less. Greater medical accuracy would have made "A book about sexually transmitted diseases" even more useful.

J M Hunter
Work for the paper on the effect of syphilitic rabbit serum on treponemal motility, attachment to mammalian cells in vitro, and infection in rabbits $(1983 ; 59$ : 220-4) was undertaken at the Department of Microbiology, Monash University Medical School, Alfred Hospital, Prahan, Victoria, Australia and not at the two institutions cited. 